Jurnal Health Sains: p-ISSN: 2723-4339 e-ISSN: 2548-1398

Vol. 3, No. 1, Januari 2022

\title{
HUBUNGAN ANTARA PENDAPATAN DENGAN SWAMEDIKASI ANTIBIOTIK AMOXICILLIN TANPA RESEP DOKTER DI DESA CIKADUT KABUPATEN BANDUNG
}

\author{
Alvianti Nuraini, Faris Mochamad Naufal \\ Fakultas Farmasi, Universitas Al-Ghifari Bandung, Jawa Barat, Indonesia \\ Email: alviantinuraiini139@gmail.com, farismn98@gmail.com
}

\begin{tabular}{ll}
\hline INFO ARTIKEL & ABSTRAK \\
\hline Diterima & Antibiotik adalah obat yang banyak digunakan pada infeksi yang \\
5 Januari 2022 & disebabkan oleh bakteri. Banyak studi penelitian menemukan adanya \\
Direvisi & penggunaan antibiotik yang tidak tepat sekitar 40-62\% untuk penyakit \\
15 Januari 2022 & yang sebenarnya tidak memerlukan antibiotik dalam penyembuhannya. \\
Disetujui & Pada penelitian kualitas penggunaan antibiotik di berbagai bagian rumah \\
25 Januari 2022 & sakit ditemukan 30\% sampai dengan 80\% tidak didasarkan pada indikasi \\
\hline Kata Kunci: & (Hadi, 2009). Antibiotik yang sering digunakan di masyarakat adalah \\
antibiotik & antibiotik amoxicilillin. Jika antibiotik jenis amoxicillin ini dikonsumsi \\
amoxicillin; & tidak sesuai aturan pakai atau tanpa anjuran dari yang berwenang \\
pendapatan; & (Dokter) maka resiko resistensi akan terus meningkat. Dampak \\
swamedikasi & negatifnya tidak hanya untuk kesehatan saja, namun pada ekonomi dan \\
& sosial pun akan ikut andil di dalamnya. Penduduk Indonesia melakukan \\
& pengobatan sendiri (swamedikasi) sudah cukup lama. Berdasarkan riset, \\
& 58,78\% penduduk melakukan penggunaan obat tanpa resep dokter. \\
& Karena tingginya angka swamedikasi maka penelitian ini bertujuan \\
& untuk mengetahui hubungan antara pendapatan dengan swamedikasi \\
& antibiotik khususnya Amoxicillin di Desa Cikadut Kecamatan Cimenyan \\
& Kabupaten Bandung. Penelitian ini menggunakan penelitian kuantitatif \\
deskriptif dan pengambilan sampel menggunakan Non Teknik Random & \\
& Sampling yaitu jenis Convenience Sampling dan purposive sampling \\
& dengan melibatkan 100 responden. Variabel yang diteliti adalah tingkat \\
& pendapatan masyarakat. Hasil penelitian menunjukkan bahwa di desa \\
& cikadut Kecamatan Cimenyan Kabupaten Bandung tidak ada pengaruh \\
& antara tingkat pendapatan dengan penggunaan antibiotik jenis \\
& amoxicillin tanpa resep dokter (swamedikasi).
\end{tabular}

\begin{abstract}
Antibiotics are drugs that are widely used in infections caused by bacteria. Many studies have found that there is an inappropriate use of antibiotics around 40-62\% for diseases that do not require antibiotics to cure. In research on the quality of use antibiotics in various parts of the hospital found $30 \%$ up to $80 \%$ is not based on indications (Hadi, 2009). Antibiotics that are often used in the community are amoxicillin antibiotics. If this type of amoxicillin antibiotic is consumed not in accordance with the rules of use or without recommendations from the community (doctors), the risk of resistance will continue to increase. The negative impact is not only on the economy and socially. will also take part in it. The Indonesian population has been doing self-medication (self-medication) for a long time. Based on research, 58.78\% of the
\end{abstract}

$\begin{array}{ll}\text { How to cite: } & \text { Nuraini. A. \& Naufal. F. M. (2022) Hubungan Antara Pendapatan dengan Swamedikasi Antibiotik } \\ & \text { Amoxicillin tanpa Resep Dokter di Desa Cikadut Kabupaten Bandung. Jurnal Health Sains 3(1). } \\ & \text { https://doi.org/10.46799/jhs.v3i1.392 } \\ \text { E-ISSN: } & 2723-6927 \\ \text { Published by: } & \text { Ridwan Institute }\end{array}$




\begin{tabular}{ll}
\hline & population uses drugs without a doctor's prescription. Due to the high \\
& rate of self-medication, this study aims to determine the relationship \\
& between income and self-medication of antibiotics, especially \\
Amoxicillin in Cikadut Village, Cimenyan District, Bandung. This study & \\
& uses descriptive quantitative research and sampling using non-random \\
& sampling technique, namely the type of convenience sampling and \\
purposive sampling involving 100 respondents. The variable studied is & the level of community income. The results showed that in Cikadut \\
Keywords: & Village, Cimenyan District, Bandung Regency, there was no influence \\
amoxicillin & between income level and the use of amoxicillin antibiotics without a \\
antibiotic; income; & doctor's prescription (self-medication). \\
self-medication &
\end{tabular}

\section{Pendahuluan}

Antibiotik merupakan obat yang paling banyak digunakan pada infeksi yang disebabkan oleh bakteri. Berbagai studi menemukan bahwa sekitar 40-62\% antibiotik digunakan secara tidak tepat antara lain untuk penyakit-penyakit yang sebenarnya tidak memerlukan antibiotik. Pada penelitian kualitas penggunaan antibiotik di berbagai bagian rumah sakit ditemukan $30 \%$ sampai dengan $80 \%$ tidak didasarkan pada indikasi (RI, 2013).

Terjadinya peningkatan resistensi kuman terhadap antibiotik karena faktor kurangnya informasi yang akurat sehingga dapat mengakibatkan tingginya tingkat konsumsi yang tidak tepat (Pratiwi et al., 2020).

Amoksisilin merupakan suatu antibiotik semisintetik penicillin yang memiliki cincin $\beta$-laktam memiliki aktivitas sebagai antibakteri yang disebabkan oleh mikroorganisme yang rentan (Meta et al., 2015). Amoksisilin termasuk antibiotik spektrum luas dan memiliki bioavailabilitas oral yang tinggi, dengan puncak konsentrasi plasma dalam waktu 1-2 jam sehingga pengkonsumsiannya sering diberikan kepada anak-anak dan juga orang dewasa. Antibiotik amoksisilin ini juga dapat digunakan pada terapi pneumonia dan penyakit lain, termasuk infeksi bakteri pada telinga, tenggorokan, sinus, kulit, saluran kemih, abdomen, dan darah. (Sofyani et al., 2018).
Swamedikasi didefinisikan oleh World Health Organization (WHO) sebagai the selection and use of medicines by individuals to treat self-recognised illnesses or symptoms. berdasarkan definisi tersebut dapat diambil pengertian bahwa swamedikasi merupakan proses pengobatan yang dilakukan sendiri oleh seseorang mulai dari pengenalan keluhan atau gejalanya sampai pada pemilihan dan penggunaan obat. Gejala penyakit yang dapat dikenali sendiri oleh orang awam adalah penyakit ringan atau minor illnesses sedangkan obat yang dapat digunakan untuk swamedikasi adalah obat-obat yang dapat dibeli tanpa resep dokter termasuk obat herbal atau tradisional (Widayati, 2013).

Berdasarkan data WHO pada tahun 2015, menyatakan bahwa Indonesia menduduki peringkat ke-8 dari 27 negara yang banyak didapati kasus resistensi bakteri terhadap antibiotik, hal ini menunjukkan bahwa penggunaan antibiotik di Indonesia tidak sesuai dengan pedomannya. Sedangkan pada tahun 2013, WHO menyebutkan bahwa terdapat 480.000 kasus Multi Drug Resistance Tuberculosis (MDRTB) di dunia (Organization, 2002). Data ini menunjukkan bahwa resistensi antibiotika memang telah menjadi masalah dalam dunia medis di dunia yang harus segera diselesaikan (Organization, 2018).

Akibat kurangnya pengetahuan masyarakat tentang pengetahuan dan penggunaan antibiotika yang benar khususnya amoxicillin, dapat menjadi faktor yang 
memicu resistensi bakteri terhadap antibiotik. Masyarakat tidak diperbolehkan membeli antibiotika sendiri tanpa ada resep dari dokter. Apabila sakit, harus melakukan pemeriksaan dan pengobatan di fasilitas pelayanan kesehatan. Antibiotika harus diminum sampai tuntas dan teratur sesuai anjuran dokter. Karena jika tidak, resistensi antibiotika akan semakin banyak terjadi dan merugikan kita semua (Zuhriyah et al., 2018).

Oleh karena itu, penggunaan obat antibiotik khususnya amoxicillin yang rasional dan sesuai dengan pedomannya dapat membantu untuk mengendalikan peningkatan kasus resistensi bakteri terhadap antibiotik. Hal ini dapat terealisasi dengan adanya keterlibatan seluruh tenaga kesehatan, khususnya farmasis untuk mengedukasi dan memberikan informasi bahwa swamedikasi hanya untuk penyakit ringan, serta mengenai penggunaan obat antibiotik yang rasional kepada masyarakat dan tenaga kesehatan lainnya. Dengan demikian, berdasarkan latar belakang tersebut, maka penulis memutuskan untuk melakukan penelitian dengan judul "Hubungan Antara Pendapatan dengan Swamedikasi Antibiotik Amoxicillin Tanpa Resep Dokter di Desa Cikadut Kabupaten Bandung"

\section{Metode Penelitian}

Penelitian ini menggunakan dua metode, yaitu penelusuran pustaka dan pendekatan kuantitatif. Pustaka yang digunakan berupa jurnal ilmiah, jurnal nasional, dan jurnal internasional. Pendekatan kuantitatif adalah penelitian yang dilakukan dengan mengumpulkan data yang berupa angka kemudian diolah dan dianalisis untuk mendapatkan suatu informasi ilmiah di balik angka-angka tersebut (Martono, 2010). Observasi dilakukan di Desa Cikadut, Kabupaten Bandung dengan mewawancarai serta menggunakan angket dan kuisioner dengan masyarakatnya sebagai sampel.
Instrumen penelitian yang digunakan yaitu alat tulis, laptop, printer, smartphone, dan kuisioner. Data yang akan digunakan pada observasi ini yaitu data dari hasil wawancara dan kuisioner menggunakan Google Form yang terdiri dari data demografi responden (nama, jenis kelamin, dan pendapatan), pengetahuan responden terhadap antibiotik dan penggunaannya, serta pengetahuan responden mengenai swamedikasi.

Populasi dalam penelitian ini adalah masyarakat Desa Cikadut, Kabupaten Bandung. Sedangkan pengambilan sampel dilakukan secara acak pada bulan Desember 2021 menggunakan metode wawancara, dengan sampel penelitian masyarakat Desa Cikadut, Kabupaten Bandung yang diwawancara dan diberikan kuisioner secara door to door.

Untuk menghitung besar sampel yang akan digunakan dalam penelitian ini digunakan perhitungan sampel menurut rumus Slovin, yaitu:

$$
\mathrm{n}=\mathrm{N} /\left(1+\mathrm{N}(\llbracket \mathrm{e}) \rrbracket^{\wedge} 2\right)
$$

\section{Keterangan:}

$\mathrm{n}=$ Ukuran sampel atau jumlah responden

$\mathrm{N}=$ Ukuran populasi

$\mathrm{e}=$ Kelonggaran ketidaktelitian atau derajat toleransi (Sugiyono, 2017).

Dalam penelitian ini, derajat toleransi atau nilai presisi tingkat kesalahan yang dikehendaki ditentukan sebesar 5\% atau sig. 0,05 , didapat berdasarkan akurasi sebesar 95\% maka jumlah sampel penelitian minimal 80. Berikut adalah perhitungan sampel dengan menggunakan rumus Slovin:

$$
\begin{aligned}
& \mathrm{n}=100 /(1+100(\llbracket 0,05) \rrbracket \wedge 2)=80 \\
& \text { Dapat disimpulkan bahwa populasi }
\end{aligned}
$$
penelitian yaitu 100 orang, sehingga jumlah minimal sampel responden yaitu 80 orang. Pengumpulan data pada penelitian ini dilakukan dengan cara wawancara dan memberikan kuisioner kepada responden dengan cara door to door. Kemudian dihubungkan antara data demografi 
responden, khususnya pendapatan, dengan pengetahuan mengenai swamedikasi dan antibiotik serta penggunaannya.

Pengolahan data dilakukan dengan mengumpulkan respon terhadap kuisioner yang diberikan melalui Google Form.

\section{Hasil dan Pembahasan}

\section{A. Hasil Penelitian}

Pada penelitian ini, dari 100 orang yang dijadikan sampel penelitian, sebanyak 60 orang tidak selalu periksa ke dokter ketika sakit dan sebanyak 84 orang pernah membeli antiniotik tanpa resep dokter dengan penggunaan antibiotik jenis amoxicillin sebanyak 69 orang. Hal ini berarti lebih dari $50 \%$ responden
Kemudian data dikerjakan secara otomatis oleh sistem, sehingga data dari hasil penelitian sudah menjelaskan karakteristik setiap variabel berdasarkan diagram dan persentase.

\section{Tabel 1}

Distribusi responden berdasarkan jenis kelamin

\begin{tabular}{|c|c|c|}
\hline Jenis Kelamin & $\begin{array}{l}\text { Jumlah } \\
\text { (orang) }\end{array}$ & $\begin{array}{c}\text { Persentase } \\
(\%)\end{array}$ \\
\hline Laki-laki & & 31 \\
\hline Perempuan & & 69 \\
\hline Total & 100 & 100 \\
\hline
\end{tabular}

Tabel 2

Distribusi responden berdasarkan pendapatan

\begin{tabular}{ccc}
\hline No. & $\begin{array}{c}\text { Tingkat Pendapatan } \\
\text { (Rupiah) }\end{array}$ & $\begin{array}{c}\text { Persentase } \\
(\mathbf{\%})\end{array}$ \\
\hline 1. & Tidak/belum bekerja & 4 \\
\hline 2. & $<1.000 .000$ & 65 \\
\hline 3. & 1.000 .000 & 12 \\
\hline 4. & $>1.000 .000$ & 18 \\
\hline 5. & $>2.000 .000$ & 1 \\
\hline Total & & 100 \\
\hline
\end{tabular}

Tabel 3

Distribusi responden berdasarkan kebiasaan berswamedikasi

\begin{tabular}{ccc}
\hline No. & $\begin{array}{c}\text { Kebiasaan } \\
\text { Berswamedikasi }\end{array}$ & Persentase (\%) \\
\hline 1. & Ya & 97 \\
\hline 2. & Tidak & 3 \\
\hline
\end{tabular}


Tabel 4

Distribusi responden berdasarkan swamedikasi antibiotik

\begin{tabular}{ccc}
\hline No. & Pernah Membeli Antibiotik Tanpa Resep Dokter & $\begin{array}{c}\text { Persentase } \\
(\mathbf{\%})\end{array}$ \\
\hline 1. & Ya & 84 \\
\hline 2. & Tidak & 16 \\
\hline Total & & 100 \\
\hline
\end{tabular}

Tabel 5

Distribusi responden berdasarkan antibiotik yang digunakan

\begin{tabular}{ccc}
\hline No. & Jenis Antibiotik & $\begin{array}{c}\text { Persentase } \\
(\mathbf{\%})\end{array}$ \\
\hline 1. & Amoxicillin & 82 \\
\hline 2. & Tetrasiklin & 2 \\
\hline 3. & Helixim & 1 \\
\hline 4. & Jenis lainnya & 2 \\
\hline 5. & Tidak tahu jenisnya & 6 \\
\hline 6. & Tidak menggunakan antibiotik untuk swamedikasi & 5 \\
\hline 7. & Pergi ke dokter & 2 \\
\hline Total & & 100 \\
\hline
\end{tabular}

Tabel 6

Alasan membeli antibiotik dalam berswamedikasi

\begin{tabular}{ccc}
\hline No. & Alasan & $\begin{array}{c}\text { Persentase } \\
(\mathbf{\%})\end{array}$ \\
\hline 1. & Lebih praktis & 53 \\
\hline 2. & Mahal apabila harus ke dokter & 8 \\
\hline 3. & Sudah cocok & 21 \\
\hline 4. & Tidak tahu harus dengan resep dokter & 3 \\
\hline 5. & Tidak/belum pernah & 10 \\
\hline 6. & Membeli dengan resep dokter & 3 \\
\hline 7. & Lebih baik berobat ke dokter & 2 \\
\hline Total & & 100 \\
\hline
\end{tabular}

Penggunaan obat antibiotik secara swamedikasi yang diteliti dalam studi ini memperlihatkan bahwa sembilan puluh tujuh dari seratus orang sampel melakukan swamedikasi dan delapan puluh empat persennya menggunakan antibiotik secara swamedikasi.

1. Hubungan antara jenis kelamin dengan penggunaan antibiotik tanpa resep dokter
Pada tabel 1, menunjukan bahwa jenis kelamin pada penggunaan obat antibiotik tanpa resep dokter di Desa Cikadut, Kabupaten Bandung, yaitu sebanyak enam puluh sembilan sampel laki-laki dan tiga puluh satu sampel perempuan. Meskipun menunjukan perbedaan jumlah responden, namun dari hasil ini tidak terdapat perbedaan yang signifikan untuk menyimpulkan bahwa jenis kelamin mempengaruhi 
tingkat penggunaan obat antibiotik tanpa resep dokter.

2. Hubungan antara Pendapatan dengan penggunaan antibiotik tanpa resep dokter

Pada tabel 2 menunjukkan bahwa tingkat pendapatan responden pada penggunaan antibiotik jenis amoxicillin di Desa Cikadut Kecamatan Cimenyan Kabupaten Bandung, responden yang paling banyak menggunakan antibiotik jenis amoxicillin tanpa resep berdasarkan tingkat pendapatan yaitu: di atas $>1.000 .000$.

3. Perbandingan antara responden yang melakukan swamedikasi dan tidak

Dari tabel 3 menunjukkan bahwa di Desa Cikadut Kecamatan Cimenyan Kabupaten Bandung, responden melakukan swamedikasi (penggunaan tanpa resep dokter) berdasarkan penelitian yaitu sebesar: $97 \%$ melakukan swamedikasi

4. Perbandingan antara responden yang melakukan swamedikasi obat antibiotik

Dari tabel 4 menunjukkan bahwa di Desa Cikadut Kecamatan Cimenyan Kabupaten Bandung, responden melakukan swamedikasi antibiotik tanpa resep dokter yaitu sebanyak: 84 $\%$

5. Perbandingan antara jenis antibiotik yang digunakan oleh responden ketika melakukan swamedikasi

Dari tabel 5 menunjukkan bahwa responden di Desa Cikadut Kecamatan Cimenyan Kabupaten Bandung melakukan swamedikasi antibiotik paling banyak yaitu: Amoxicillin 82\%

6. Alasan responden ketika menggunakan antibiotik tanpa resep dokter

Dari tabel 6 menunjukkan bahwa responden di Desa Cikadut Kecamatan Cimenyan Kabupaten Bandung merasa bahwa lebih praktis langsung membeli antibiotik amoxicillin dan tidak perlu lama mengantri di instansi kesehatan (dokter) sebanyak 53\%, dan responden dengan tingkat kepercayaan bahwa jika ke dokter akan mendapat resep antibiotik jenis amoxicillin atau bisa di katakan sudah cocok dan pernah berobat dengan amoxicillin sebanyak $21 \%$ responden mengira jika dengan sakit atau keluhan yang sama maka antibiotik yang digunakan adalah sama. Sedangkan responden yang mempertimbangkan aspek ekonomi sebagai alasan menggunakan obat antibiotik tanpa resep dokter sebanyak $8 \%$.

Dari hasil riset kuisioner pada tabel di atas, dapat dilihat bahwa hubungan antara pendapatan dan penggunaan obat antibiotik responden dengan pendapatan di atas satu juta namun kurang dari dua juta lebih sering membeli obat, khususnya antibiotik amoxicillin ke apotek tanpa resep dokter. Akan tetapi data tersebut tidak bisa menyimpulkan secara langsung bahwa pendapatan berpengaruh besar terhadap tingkat penggunaan obat antibiotik tanpa resep dokter, karena pada tabel yang lainnya, responden cenderung memilih alasan supaya praktis saat membeli obat antibiotik tanpa resep dokter ke apotek, dibandingkan dengan masalah ekonomi (Rahmawati \& Budiono, 2013).

Responden yang cenderung membeli obat antibiotik amoxicillin langsung ke apotek tanpa resep dokter disebabkan oleh responden merasa bahwa lebih praktis langsung membeli antibiotik amoxicillin dan tidak perlu lama mengantri di instansi kesehatan (dokter) (Valentina Meta et al., 2018). Kemudian ada juga responden yang merasa percaya bahwa jika pergi ke dokter sudah pasti akan mendapat resep obat untuk antibiotik jenis amoxicillin atau bisa dikatakan sudah merasa cocok dengan obat antibiotik 
amoxicillin, sehingga enggan untuk pergi ke instansi kesehatan untuk memeriksa diri karena mengira jika dengan sakit atau keluhan yang sama, maka antibiotik yang digunakan adalah sama seperti yang diberikan sebelumnya. Sedangkan responden yang mempertimbangkan aspek ekonomi cenderung lebih sedikit jika dibandingkan dengan aspek praktis dan kecocokan.

Di samping itu, terdapat responden yang merasa tidak tahu harus membeli obat antibiotik dengan resep dokter. Meski persentasenya kecil (3\%), hal ini tentunya harus menjadi perhatian seluruh tenaga kesehatan, khususnya farmasis untuk mengedukasi dan memberikan informasi bahwa swamedikasi hanya untuk penyakit ringan, serta mengenai penggunaan obat antibiotik yang rasional kepada masyarakat dan tenaga kesehatan lainnya. Dengan demikian, kasus resistensi bakteri terhadap antibiotik dapat diminimalisir dengan cara mengedukasi dan memberikan informasi mengenai penggunaan obat antibiotik khususnya amoxicillin yang rasional dan sesuai dengan pedomannya (Desrini, 2015).

Pada intinya, hubungan antara pendapatan dengan penggunaan obat antibiotik jenis amoxicillin tidak berpengaruh besar meski terdapat perbedaan jumlah responden. Hal ini disebabkan oleh responden cenderung memilih solusi yang lebih praktis, yaitu tidak menghabiskan banyak waktu dan tenaga dibandingkan dengan memperhatikan aspek ekonomi. Adapun responden yang tidak tahu herus membeli obat antibiotik dengan resep dokter harus menjadi bahan evaluasi tenaga kesehatan, khususnya farmasis untuk lebih aktif dalam mengedukasi dan memberikan informasi mengenai penggunaan obat antibiotik yang rasional dan sesuai dengan pedomannya.

\section{Kesimpulan}

Berdasarkan penelitian yang dilakukan oleh penulis kepada masyarakat di Desa Cikadut Kabupaten Bandung, pada bulan Desember 2021 sampai dengan Januari 2022, maka dapat disimpulkan bahwa tingkat pendapatan tidak mempengaruhi penggunaan obat antibiotik jenis amoxicillin tanpa resep dokter (swamedikasi).

\section{BIBLIOGRAFI}

Desrini, S. (2015). Resistensi Antibiotik, Akankah Dapat Dikendalikan? Jurnal Kedokteran Dan Kesehatan Indonesia, 6(4). Google Scholar

Martono, N. (2010). Metode Penelitian Kuantitatif: Analisis Isi Dan Analisis Data Sekunder (Sampel Halaman Gratis). Rajagrafindo Persada. Google Scholar

Meta, V., Wineini, R. B., \& Intannia, D. (2015). Peresepan Antibiotik Pada Pasien Anak Rawat Jalan Di Blud Rs Ratu Zalecha Martapura: Prevalensi Dan Pola Peresepan Obat. Prosiding Seminar Nasional \& Workshop "Perkembangan Terkini Sains Farmasi \& Klinik 5," 5, 268-273. Google Scholar

Organization, W. H. (2002). Safety of Medicines: A Guide To Detecting And Reporting Adverse Drug Reactions: Why Health Professionals Need To Take Action. World Health Organization. Google Scholar

Organization, W. H. (2018). Who Expert Consultation On Rabies: Third Report (Vol. 1012). World Health Organization. Google Scholar

Pratiwi, A. I., Wiyono, W. I., \& Jayanto, I. (2020). Pengetahuan Dan Penggunaan Antibiotik Secara Swamedikasi Pada Masyarakat Kota. Jurnal Biomedik: Jbm, 12(3), 176-185. Google Scholar 
Hubungan Antara Pendapatan dengan Swamedikasi Antibiotik Amoxicillin tanpa Resep Dokter di Desa Cikadut Kabupaten Bandung

Rahmawati, I., \& Budiono, U. (2013). Sensitivitas Antibiotik Pada Pasien Sepsis Di Intensive Care Unit Rumah Sakit Dr. Kariadi Semarang Periode 1 Januari-31 Desember 2011. Faculty Of Medicine Diponegoro University. Google Scholar

Ri, K. (2013). Riset Kesehatan Dasar 2013. Jakarta: Kementerian Kesehatan Republik Indonesia, 16. Google Scholar

Sofyani, C. M., Chaerunnisa, A. Y., \& Rusdiana, T. (2018). Validasi Metode Analisis Kromatografi Cair Kinerja Tinggi Untuk Penetapan Kadar Uji Disolusi Terbanding Tablet Amoksisilin. Farmaka, 16(1), 324-330. Google Scholar

Sugiyono, P. D. (2017). Metode Penelitian Bisnis: Pendekatan Kuantitatif, Kualitatif, Kombinasi, Dan R\&D. Penerbit Cv. Alfabeta: Bandung. Google
Scholar

Valentina Meta, S., Wineini, R. B., \& Intannia, D. (2018). Peresepan Antibiotik Pada Pasien Anak Rawat Jalan Di Blud Rs Ratu Zalecha Martapura: Prevalensi Dan Pola Peresepan Obat. Google Scholar

Widayati, A. (2013). Swamedikasi Di Kalangan Masyarakat Perkotaan Di Kota Yogyakarta. Jurnal Farmasi Klinik Indonesia, 2(4), 145-152. Google Scholar

Zuhriyah, A., Februyani, N., \& Jamilah, L. A. (2018). Tingkat Pengetahuan Penggunaan Antibiotik Jenis Amoxicillin Pada Masyarakat Desa Pilanggede Kecamatan Balen Kabupaten Bojonegoro. Jurnal Ilmiah Hospitality, 7(2), 41-48. Google Scholar

\section{Copyright holder:}

Alvianti Nuraini, Faris Mochamad Naufal (2022)

First publication right:

Jurnal Health Sains

This article is licensed under:

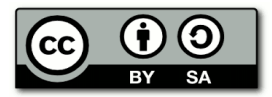

